УдК 793.3:7.071]:929

DOI: 10.31866/2616-7646.4.2.2021.249305

\title{
БІОГРАФІЧНИЙ МЕТОД У ДОСЛІДЖЕННІ ЖИТТЯ ТА ТВОРЧОСТІ ДІЯЧІВ ХОРЕОГРАФІї
}

\author{
Підлипський Андрій Ігорович, \\ кандидат мистецтвознавства, старший викладач, \\ Київський національний університет культури і мистецтв, \\ Київ, Україна, \\ https://orcid.org/0000-0001-8086-3532, \\ pidlipqukr.net \\ Аксьонов Олександр Борисович, \\ провідний концертмейстер, \\ Київський національний університет культури і мистецтв, \\ Київ, Україна, \\ https://orcid.org/0000-0002-1870-524X, \\ shousindi.ua
}

Мета статті - виявити складники біографічного методу та обгрунтувати раціональність його застосування в процесі проведення досліджень, присвячених діячам хореографічної культури. Методологія. Під час проведення дослідження застосовано аналітичний, компаративний, дедуктивний методи, а також метод теоретичного узагальнення для формулювання висновків. Наукова новизна. Вперше в українській хореології обгрунтовано доцільність використання біографічного методу крізь призму феноменології. Висновки. Методологічний ракурс осмислення хореографічної культури у площині феноменології має виняткове значення, оскільки дозволяє розглянути проблеми, які постають перед нею на загальнонаціональному, регіональному та місцевому рівнях крізь призму історичного минулого та перспектив майбутнього розвитку. Принципи феноменологічного аналізу можна застосувати, досліджуючи біографії діячів хореографічного мистецтва. Важливим $\epsilon$ не лише аналіз об’єктивних фактів біографії, а й інтерпретація духовних проявів особистості, що виявляються в результатах іiї діяльності. Лише поєднання раціональних та ірраціональних підходів у процесі застосування біографічного методу стає запорукою проведення комплексного дослідження. Біографічний метод передбачає врахування такого феномену, як «життєвий досвід» чи «світ людини», що тлумачиться як унікальна територія досвіду конкретної людини. Біографії особистостей, що прислужились розвитку хореографічної культури України, є важливою з позицій сучасної гуманістичної парадигми та збільшення людиноцентричних досліджень.

Ключові слова: біографічний метод; хореографія; хореографічна культура; феноменологія. 


\section{БИОГРАФИЧЕСКИЙ МЕТОД В ИССЛЕДОВАНИИ ЖИЗНИ И ТВОРЧЕСТВА ДЕЯТЕЛЕЙ ХОРЕОГРАФИИ}

\author{
Пидлыпский Андрей Игоревич, \\ кандидат искусствоведения, старший \\ преподаватель, \\ Киевский национальный университет \\ культуры и искусств, \\ Киев, Украина, \\ https://orcid.org/0000-0001-8086-3532, \\ pidlipQukr.net
}

Аксёнов Александр Борисович, ведущий концертмейстер, Киевский национальный университет культуры и искусств, Киев, Украина,

https://orcid.org/0000-0002-1870-524X shousindi.ua

Цель статьи - выявить составляющие биографического метода и обосновать рациональность его применения при проведении исследований, посвященных деятелям хореографической культуры. Методология. При проведении исследования использован аналитический, компаративный, дедуктивный методы, а также метод теоретического обобщения для формулирования выводов. Научная новизна. Впервые в украинской хореологии обоснована целесообразность использования биографического метода через призму феноменологии. Выводы. Методологический ракурс осмысления хореографической культуры в плоскости феноменологии имеет исключительное значение, поскольку позволяет рассмотреть возникающие перед ней проблемы на общенациональном, региональном и местном уровнях, сквозь призму исторического прошлого и перспектив будущего развития. Принципы феноменологического анализа можно применить при исследовании биографий деятелей хореографического искусства. Важен не только анализ объективных фактов биографии, но и интерпретация духовных проявлений личности, обнаруживающихся в результа-

\section{BIOGRAPHICAL METHOD \\ IN THE STUDY OF LIFE AND WORK OF CHOREOGRAPHERS}

\author{
Andrii Pidlypskyi, \\ PhD in Art Studies, \\ Senior Lecturer, \\ Kyiv National University \\ of Culture and Arts, \\ Kyiv, Ukraine, \\ https://orcid.org/0000-0001-8086-3532, \\ pidlipQukr.net

\section{Oleksandr Aksonov,} \\ Leading Accompanist, \\ Kyiv National University \\ of Culture and Arts, \\ Kyiv, Ukraine, \\ https://orcid.org/0000-0002-1870-524X, \\ shousindi.ua
}

The purpose of the article is to identify the components of the biographical method and justify the rationality of its use in conducting studies on choreographic cultural figures. Methodology. Analytical, comparative, deductive methods, as well as the method of theoretical generalization, were used in the study to formulate conclusions. Scientific novelty. For the first time in Ukrainian choreology, the expediency of using the biographical method through the prism of phenomenology is substantiated. Conclusions. The methodological perspective of understanding choreographic culture in the field of phenomenology is extremely important because it allows us to consider the problems facing it at the national, regional and local levels, through the prism of historical past and prospects for future development. The principles of phenomenological analysis can be applied in the study of choreographers' biographies. It is important not only to analyze the objective facts of the biography but also to interpret the spiritual manifestations of the individual, which are manifested in the results of his activities. Only a combination of rational and irrational approaches in the process of applying the biographical method becomes the key to a comprehensive study. 
тах ее деятельности. Только сочетание рациональных и иррациональных подходов в процессе внедрения биографического метода становится залогом проведения комплексного исследования. Биографический метод предполагает учет такого феномена, как «жизненный опыт» или «мир человека», толкуемый как уникальная территория опыта конкретного человека. Биографии личностей, которые послужили развитию хореографической культуры Украины, важны с позиций современной гуманистической парадигмы и увеличения человекоцентрических исследований.

Ключевые слова: биографический метод; хореография; хореографическая культура; феноменология.
The biographical method takes into account such a phenomenon as 'life experience' or 'human world', which is interpreted as a unique area of a particular person's experience. Biographies of individuals who have contributed to the development of a choreographic culture of Ukraine are important from the standpoint of the modern humanistic paradigm and the increase of human-centred research.

Keywords: biographical method; choreography; choreographic culture; phenomenology.

Актуальність теми дослідження. Гуманістична парадигма розвитку сучасного суспільства відкриває широкі перспективи для дослідження біографій митців в оновленій методології гуманітаристики. Важливими для заповнення лакун в історії української хореографічної культури є проведення досліджень, присвячених окремим особистостям, що творили вітчизняне танцювальне мистецтво. Для реалізації цього наукового напряму актуальним є розроблення методології, де важливе місце посідає біографічний метод.

Аналіз останніх досліджень та публікацій. Праці, присвячені окремим діячам хореографічної культури, постійно з'являються в науковому дискурсі. Серед них фундаментальні дослідження біографій К. Василенка (Жиров, 2007), П. Вірського (Станішевський, 1962), М. Трегубова (Чурпіта, 2018) та ін.; статті, присвячені М. Вантуху (Шумілова, 2018), О. Колоску (Гутник, 2020), І. Николишину (Підлипський, 2018) та ін. Але вони не реалізують усього потенціалу біографічного методу. Чи не єдина стаття, яка порушує проблему застосування біографічного методу, належить Н. Корисько, що досліджувала творчість балетмейстера П. Вірського (2013). Але спеціального розгляду біографічного методу з позицій феноменологічного підходу досі проведено не було.

Мета статті - виявити складники біографічного методу та обгрунтувати раціональність його застосування при проведенні досліджень, присвячених діячам хореографічної культури.

Виклад основного матеріалу. Фундаментальна особливість біографічного методу полягає у спрямованості на відтворення історичної, розгорнутої у часі ретроспективи танцювальних подій у хореографічному просторі тієї чи іншої локації. Отже, в центрі уваги біографічного дискурсу - вивчення перебігу життєвого шляху людини (у випадку з хореографією - балетмейстера, виконавця, сценографа, композитора та ін.), його внутрішня динаміка, «вбудованість» у соціум і набутий індивідуальний та соціальний життєвий досвід. Водночас біографічне дослідження передбачає необхідність врахування взаємозв’язку індивідуальної історії 
життя з конкретною культурно-історичною епохою, на тлі якої реалізуються чи не реалізуються, чи реалізуються неповною мірою життєві сценарії.

Теоретико-методологічною основою біографічного методу є феноменологія, яка визнає життя кожної людини як самодостатній, наповнений глибоким смислом феномен. Водночас визнає можливість спонтанно-смислового опису цього феномену.

Принципи феноменологічного аналізу, який можна застосувати в процесі дослідження біографій митців хореографії, розроблені німецьким мислителем Е. Гуссерлем упродовж трьох періодів власне феноменологічного етапу його філософії: період «дескриптивної» (чи «ейдетичної»), «трансцендентальної» і «генетичної» феноменології. Гуссерль (2005) розглядав свою феноменологію як метод, що описує універсальні механізми роботи свідомості; метод, на основі якого можна побудувати за аналогією з системою природничих наук нову систему гуманітарного знання.

Як пише дослідник його філософії В. Куренной (2005), «... феноменологія займається не поясненням, яке превалює у більшості наук, але описом (дескрипці-

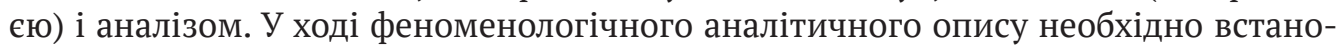
вити сутнісні відмінності, яким підпорядковані всі інші стосунки, що фіксуються у нашому житті. Ці стосунки... є апріорними (сутнісними чи, як висловлюється Гуссерль, “ейдетичними”)» (с. 18).

До цих принципів належать: уявлення про свідомість як інтенціональність, антиредукціонізм, дескриптивний метод, емпатія, епохе, ейдетичне бачення. Принципово важливими у феноменологічній епістемології є поняття інтенціональності, запозичене у А. Брентано, але модифіковане Гуссерлем й означене як «спрямованість на», тобто процес свідомості, що завжди є свідомістю про щось, свідомістю про об’єкти, «незалежно від того, чи реальні самі об’єкти чи ні». I саме інтенціональна характеристика $є$ структурним моментом життя нашої індивідуальної свідомості, носієм «об'єктивного смислу», смислу «самого по собі», а відтак $\mathrm{i}$ «сутнісним», $\mathrm{i}$ «апріорним» складником свідомості.

Як основоположні принципи феноменології хореографічного мистецтва необхідно розглядати : виявлення, систематизацію та узагальнення танцювальних феноменів; їхній компаративний аналіз (хореографічну компаративістику); антиредукціонізм, який доводить, що танець в сутності своїй феномен, який неможливо повною мірою осягнути виключно у якомусь одному дискурсі: культурному, хореографічному, соціальному та ін.; емпіричну спрямованість досліджень, в основі яких лежить вивчення конкретного танцювального матеріалу, узагальнення якого дозволяє виявити закономірності розвитку танцювального мистецтва й формування хореографічної культури; епохе - принцип, спрямований на реалізацію наукової об’єктивності, орієнтований на елімінацію ціннісних установок, що перетворює дослідника на «незацікавленого спостерігача»; емпатія як принцип, що вимагає від дослідника ставлення до танцю 3 почуттям благоговіння, а у викладачів до своїх учнів з почуттям поваги.

Водночас варто враховувати, що згідно з Гуссерлем, ейдетичне бачення передбачає неможливість пізнання ейдосів (сутності феноменів свідомості) за допомогою методів доведення, поширених у природничих науках, а їхнє осягнення можливе лише за допомогою інтуїції. Слід зауважити, що це положення важливе з огляду на те, що дослідники танцювального мистецтва й хореографічної культури 
повинні мати власний танцювальний досвід, оскільки саме завдяки йому можливе «ейдетичне бачення». Це «бачення» включає в себе не лише «бачення» сутнісних ознак танцювальних явищ, а також і емпатію як здатність розпредметити й вербально репрезентувати власний танцювальний (педагогічний) досвід, що може загрожувати деяким суб'єктивізмом. Саме на це звертав увагу Е. Гуссерль. Тобто, з одного боку - метод «епохе», використання якого має забезпечити об'єктивність дослідження, з іншого боку - метод «ейдетичного бачення», що надає дослідженню суб’єктивізму. I, на перший погляд, ці методи суперечать один одному. Однак у теорії Гуссерля вони гармонійно доповнюють один одного, що знаходить підтвердження у дослідженнях діяльності хореографів та виконавців-танцівників.

У цьому контексті важливим є поняття «життєвий світ», яке вводить у науковий обіг Е. Гуссерль і за допомогою якого він здійснює спробу пов'язати науку й світогляд, раціоналізм та ірраціоналізм. Мислитель виходить з примату повсякденного життя над наукою, над раціоналізмом, оскільки останній не здатний до цілісного сприйняття «життєвого світу». Цей останній репрезентується в українських народних танцях через символи, моделі поведінки, психічні реакції та інші пласти української народної культури.

У структурі біографічного дискурсу значне місце належить категорії життєвого досвіду, яку вводить В. Дільтей, німецький історик культури, один із представників філософії життя у контексті теорії наук «про дух» (нім. Geisteswissenschaft), які докорінно відрізняються від природничих наук. I тим самим започатковує розробку гносеологічної й методологічної проблематики соціально-гуманітарного пізнання, обумовленого життєвою практикою. Автономність наук про дух простежується через зв’язок понять «життя» $\mathrm{i}$ «розуміння», відсутніх як у природничих науках, так і в самій природі.

Життєвий досвід постає як сукупність процесів, під час яких відбувається випробовування особистістю як життєвих цінностей, так і цінності речей, що дозволяє подолати розрив внутрішнього і зовнішнього, унікального і типового, суб'єктивного і об’єктивног, життєво-душевного і духовно-культурного (Дильтей, 2000).

Проблема духовної реальності пов’язана з ціннісними установками, основами й критеріями людської діяльності, що визначають її конкретні форми і $є$ результатом історичної практики. У філософії В. Дільтея розуміння постає як складний герменевтичний процес, що грунтується на інтуїтивному осягненні буття людини в широкому діапазоні екзистеціалів її особистого життя; об'єктивний аналіз, заснований на оперуванні певними узагальненнями і поняттями; семіотична реконструкція проявів її життя, що дозволяє представити буття у всій його «цілісності», наповненості як життєвим, так й історичним досвідом.

Водночас головну увагу філософ приділяв інтерпретації духовних проявів особистості, що виявляються в результатах її діяльності. А метод інтерпретації дозволяє включити в предметну сферу дослідження творчості фахівців хореографічного мистецтва такі аспекти життя особистості, як система цінностей, соціальний досвід, ментальність та ідентичність, екзистенціали її буття (щастя і свобода, доля і воля), й тим самим осмислити модель поведінки суб'єкта, що важливо у зв'язку із неоднозначністю природи людини, з ії індивідуальними суперечливими внутрішніми інтенціями. 
Життя й переживання, згідно з концепцією В. Дільтея, перетворюються на об’єктивний дух, об’єктивуючись як у різних інституціях, так і в численних релігійних, філософських, етичних, художніх системах, а в нашому випадку - в системі хореографічної культури. Історична рефлексія, пов’язана з «історичним розумом», поняттям, яке також розробляє німецький філософ, є джерелом наук про дух - історії, філософії, політичної економії, психології, правових дисциплін, наук про державу, релігію, літературу, образотворчого мистецтва, музики. Серед наук про дух чільне місце має належати й хореології, яка розробляється й на вітчизняному грунті.

У сучасній філософії й методології науки відбувається зближення процесів пізнання й творчості, що так само стає основою «екзистенціальної філософії науки», в оптиці якої виявляються специфіка діяльності, наприклад, П. Вірського в аспекті його орієнтації на поєднання високого професіоналізму керівника танцювального колективу та балетмейстера 3 формуванням хореографічного світогляду й ціннісно-моральних установок. Можна інтерпретувати традиції екзистенціалізму в межах методології біографічного аналізу, виявляючи драматизм творчої долі митця, що пішов із життя в розквіті педагогічної та балетмейстерської творчості.

Американський психолог Генрі Мюрей, грунтуючись на концептуальних положеннях 3. Фрейда, А. Адлера і К. Юнга, ввів у практику термін «персонологія» (1938р.), розуміючи під останньою унікальність особистості та вчинки, які пов’язані з її мотиваційною сферою. Б. Ананьєв, відомий психолог, фундатор акмеології, розглядав біографічний метод як «збирання даних про життєвий шлях людини як особистості і суб'єкта діяльності». Вчений виокремив два методи дослідження історії розвитку людини: онтогенетичний і генетично-персоналістичний. У межах першого особлива увага приділяється впливу генів на розвиток індивідуума. Але в аспекті мистецтвознавчого дослідження важливого значення набуває саме другий, оскільки він акцентує необхідність аналізу життєвого шляху особистості та подій різного значення, що постають на цьому шляху (Ананьев, 2001), що торує шлях до осмислення специфіки набуття танцювального досвіду у його особистісній формі, до розгляду різних сфер хореографічної рефлексії через «призму» особистості конкретної людини.

Біографічний метод як опис окремих випадків (case study) сягає часів греко-римської античності, але на початку XX ст. розробляється на принципах феноменології та герменевтики, поєднуючи ці традиції. I сьогодні він представляє пластичну, поліваріантну методологічну конструкцію, що уможливлює застосування різних методологічних підходів, їх різну модифікацію та процедурні особливості.

Комплексне біографічне дослідження включає, на думку Л. Логунової (2016), три аспекти: біолого-біографічний (умови життя, його наповненість, особливості поведінки); історико-психологічний (історія формування системи ціннісних координат, переживань і почуттів); психолого-соціальний (історія творчості).

Послуговуючись біографічним методом, можна проаналізувати масив емпіричних даних, що формується, за висловом Л. Логунової, з «документів життя». «За сутністю, об’єктом аналізу стає все людське. Саме життя - це документ, його можна досліджувати як соціокультурний текст. Елементами аналізу такого “тексту” стає особистість респондента в усіх деталях його соціального оточення й продуктах діяльності (творчість, професійна, дозвіллєва діяльність, артефакти, особисті речі, предмети побуту, нагороди), умови та місця проживання, матеріа- 
ли сімейних архівів (візуального та наративного характеру)... Біографічний метод у контексті дослідження особистості визначає розуміння світу людини як території унікального досвіду», - пояснює Л. Логунова (2016, с. 18). Біографічний метод, зважаючи на його фундаментальну особливість - спрямованість на відтворення історичної, розгорнутої у часі перспективи подій, дозволив відтворити в історичній ретроспективі діяльність О. Колоска (Гутник, 2020), І. Николишина (Підлипський, 2018), М. Трегубова (Чурпіта, 2018) та ін.

Важливо зупинитися на працях науковців, що розробляють проблематику ролі особистості в історії. Так, зокрема, Т. Воропаєва пропонує інтегративно-наукові підходи до аналізу ролі особистості в українській історії крізь призму біографістики. «Інтегративна науково-дослідна стратегія, що базується на взаємопроникненні індивідуально-біографічного, суб’єктно-діяльнісного та соціально-типологічного підходів, дає змогу громадянам України усвідомити себе як дієвих суб'єктів української історії, відчути свою співпричетність до історії своєї Батьківщини, переконатися, що творцем історії є особистість, життя й доля якої невіддільні від життя й долі свого народу; дає можливість більш точно зрозуміти специфіку іншої епохи; відкриває бачення перспектив цивілізаційного поступу та історичної місії українства», - стверджує Т. Воропаєва (2016, с. 64), аргументовано доводячи важливість дослідження персонального плану українців.

Проблеми ролі особистості в історії досліджує Л. Гринін. Науковець стверджує, що в добу глобалізації звернення до цієї теми є необхідним. Він вважає, що роль особистості обернено пропорційна стабільності й міцності суспільства, адже найбільший вплив на суспільну свідомість особистості мають саме в періоди революцій та створення нового порядку (Гринин, 2011). Екстраполюючи погляди Л. Гриніна у площину хореографічної культури, можна стверджувати, що хореографи-лідери не втратили свого авторитету, відіграли значну роль у збереженні та розвитку народно-сценічного та інших різновидів танцю в Україні в період соціокультурних трансформацій початку 1990-х рр. та в час створення нової системи функціонування аматорського та професійного мистецтва в незалежній Україні. Концепція Л. Гриніна додатково підтверджує важливість аналізу біографій митців, що прислужилися розвитку хореографічної культури.

Відомий філософ і культуролог Сергій Кримський (2003) наполягає на принципі монадності (індивідуалізації) особистості, що стверджує унікальність її світу, здатного репрезентувати свою епоху, культуру, націю. Автор вважає, що культура i, в цілому, культурно-історичний процес репрезентує неповторні риси індивідуального життя пересічної людини й життя історичної особистості, а також особливості етносів і націй.

У спільній праці Юрія Пахомова, Сергія Кримського, Юрія Павленка «Шляхи та роздоріжжя сучасної цивілізації» (Пахомов та ін., 1998) обстоюється концепція того, що в сучасному світі ефект монадності став надбанням не лише вождів і пророків (як це було в минулому), але і багатьох людей (показовою є назва останнього розділу «Людський інтелект та духовність на рубежі тисячоліть»). Автори наполягають, що лише духовно багата, монадна людина усвідомлює свою відповідальність перед природою, суспільством і самим собою.

Наукова новизна. Вперше в українській хореології обгрунтовано доцільність використання біографічного методу крізь призму феноменології. 
Висновки. Методологічний ракурс осмислення хореографічної культури у площині феноменології має виняткове значення, оскільки дозволяє розглянути проблеми, які постають перед нею на загальнонаціональному, регіональному та місцевому рівнях, крізь призму історичного минулого та перспектив майбутнього розвитку.

Принципи феноменологічного аналізу можна застосувати в процесі дослідження біографій діячів хореографічного мистецтва. Важливим $є$ не лише аналіз об’єктивних фактів біографії, а й інтерпретація духовних проявів особистості, що виявляються в результатах її діяльності. Лише поєднання раціональних та ірраціональних підходів у процесі застосування біографічного методу стає запорукою проведення комплексного дослідження. Біографічний метод передбачає врахування такого феномену, як «життєвий досвід» чи «світ людини», що тлумачиться як унікальна територія досвіду конкретної людини.

Біографія особистостей, що прислужились розвитку хореографічної культури України, є важливою з позицій сучасної гуманістичної парадигми та збільшення людиноцентричних досліджень.

\section{СПИСОК ПОСИЛАНЬ}

Ананьев, Б. Г. (2001). Человек как предмет познания (3-е изд.). Питер.

Воропаєва, Т. С. (2016). Роль особистості в українській історії крізь призму біографістики. українська біографістика, 14, 50-70.

Гринин, Л. Е. (2011). Личность в истории: современные подходы. История и современность, 1, 3-40.

Гуссерль, Э. (2005). Избранные работы (В. А. Куренной, сост.). Территория будущего.

Гутник, I. М. (2020). Становлення творчої особистості Олександра Колоска як виконавця та балетмейстера. Вісник Національної академії керівних кадрів культури і мистецтв, 3, 127-132.

Дильтей, В. (2000). Собрание сочинений в 6 т. (Т. 1: Введение в науки о духе; А. В. Михайлов \& Н. С. Плотников, ред.; В. С. Малахов, пер.). Дом интеллектуальной книги.

Жиров, О. А. (2007). Розвиток української народної хореографії у мистецько-педагогічній спадщині та діяльності К. Василенка (50-90 роки XX cm.) [Дисертація кандидата педагогічних наук, Житомирський державний університет імені Івана Франка].

Корисько, Н. М. (2013). Актуальність дослідження творчої діяльності П. Вірського застосуванням біографічного методу. Вісник КНУКіМ. Серія: Мистецтвознавство, 28, 73-78.

Кримський, С. Б. (2003). Заклики духовності ХХІ століття: (3 циклу щорічних лекцій імені А. Оленської-Петришин, 2002 р.). Академія.

Куренной, В. (2005). Феноменология Эдмунда Гуссерля. В Э. Гуссерль, Избранные работы (с. 7-22). Территория будущего.

Логунова, Л. Ю. (2016). Биографический метод в исследовании личности: методология и архитектоника. Вестник Кемеровского государственного университета. Серия: Политические, социологические и экономические науки, 1, 17-23. https://doi.org/10.21603/25003372-2016-1-17-23

Пахомов, Ю. Н., Крымский, С. Б., \& Павленко, Ю. В. (1998). Пути и перепутья современной цивилизации. Международный деловой центр.

Підлипський, А. (2018). Внесок Ігоря Николишина у розвиток народно-сценічної хореографії України. Мистецтвознавчі записки, 33, 352-359. 
Станішевський, Ю. О. (1962). Павло Павлович Вірський: Народний артист СРСР. Державне видавництво образотворчого мистецтва і музичної літератури УРСР.

Чурпіта, Т. М. (2018). Микола Трегубов: життя і творчість. НАКККіМ.

Шумілова, В. В. (2018). Початковий етап становлення творчої особистості Мирослава Михайловича Вантуха (до 80-річчя від дня народження). Міжнародний вісник: Культурологія. Філологія. Музикознавство, 2, 199-204.

\section{REFERENCES}

Ananiev, B. (2001). Chelovek kak Predmet Poznaniya [Human as a Subject of Knowledge] (3rd ed.). Piter [in Russian].

Churpita, T. (2018). Mykola Trehubov: Zhyttia i Tvorchist [Mykola Trehubov: Life and Work]. NAKKKiM [in Ukrainian].

Dilthey, W. (2000). Sobranie Sochinenii v 6 Tomakh [Collected Works in 6 Volumes] (Vol. 1; A. Mikhailov \& N. Plotnikov, Eds.; V. Malakhov, Trans.). Dom intellektual'noi knigi [in Russian].

Grinin, L. (2011). Lichnost v Istorii: Sovremennye Podkhody [Personality in History: Modern Approaches]. Istoriia i Sovremennost [History and Modernity], 1, 3-40 [in Russian].

Gutnyk, I. (2020). Stanovlennia Tvorchoi Osobystosti Oleksandra Koloska yak Vykonavtsia ta Baletmeistera [Formation of Oleksandr Kolosok Creative Personality as a Performer and Choreographer]. Visnyk Natsionalnoi Akademii Kerivnykh Kadriv Kultury i Mystetstv [National Academy of Managerial Staff of Culture and Arts Herald], 3, 127-132. https://doi. org/10.32461/2226-3209.3.2020.220116 [in Ukrainian].

Husserl, E. (2005). Izbrannye Raboty [Selected Works] (V. Kurennoy, Comp.). Territoriya budushchego [in Russian].

Korysko, N. (2013). Aktualnist Doslidzhennia Tvorchoi Diialnosti P. Virskoho Zastosuvanniam Biohrafichnoho Metodu [Relevance of the Study of P. Virsky's Creative Activity Using the Biographical Method]. Visnyk KNUKiM. Seriia: Mystetstvoznavstvo [Bulletin of KNUKiM. Series in Arts], 28, 73-78 [in Ukrainian].

Krymskyi, S. (2003). Zaklyky Dukhovnosti XXI Stolittia: (Z Tsyklu Shchorichnykh Lektsii imeni A. Olenskoi-Petryshyn, 2002 r.) [Appeals to the Spirituality of the XXI Century: (From the Series of Annual Lectures named after A. Olenska-Petryshyn, 2002)]. Akademia [in Ukrainian].

Kurennoy, V. (2005). Fenomenologiya Edmunda Gusserlya [Phenomenology of Edmund Husserl]. In E. Husserl, Izbrannye Raboty [Selected Works] (pp. 7-22). Territoriya budushchego [in Russian].

Logunova,L.(2016). Biograficheskii Metod v Issledovanii Lichnosti: Metodologiya i Arkhitektonika [Biographical Method in the Study of Personality: Methodology and Architectonics]. Vestnik Kemerovskogo Gosudarstvennogo Universiteta. Seriya: Politicheskie, Sotsiologicheskie i Ekonomicheskie Nauki [Bulletin of Kemerovo State University. Series: Political, Sociological and Economic Sciences], 1, 17-23. https://doi.org/10.21603/2500-3372-2016-1-17-23 [in Russian].

Pakhomov, Yu., Krymskiy, S., \& Pavlenko, Yu. (1998). Puti i Pereput'ya Sovremennoi Tsivilizatsii [Paths and Crossroads of Modern Civilization]. Mezhdunarodnyi delovoi tsentr [in Russian].

Pidlypskyi, A. (2018). Vnesok Ihoria Nykolyshyna u Rozvytok Narodno-Stsenichnoi Khoreohrafii Ukrainy [Ihor Nykolyshyn's Contribution to the Development of the Folk-Stage Choreography of Ukraine]. Mystetstvoznavchi Zapysky [Notes on Art Criticism], 33, 352-359 [in Ukrainian].

Shumilova, V. (2018). Pochatkovyi Etap Stanovlennia Tvorchoi Osobystosti Myroslava Mykhailovycha Vantukha (do 80-richchia vid Dnia Narodzhennia) [The Initial Stage of Formation of the Creative Personality of Myroslav Mykhailovych Vantukh (to the 80th 
Anniversary of His Birth)]. Mizhnarodnyi Visnyk: Kulturolohiia. Filolohiia. Muzykoznavstvo [International Journal: Culturology. Philology. Musicology], 2, 199-204 [in Ukrainian].

Stanishevskyi, Yu. (1962). Pavlo Pavlovych Virskyi: Narodnyi artyst SRSR [Pavlo Pavlovych Virsky: People's Artist of the USSR]. Derzhavne vydavnytstvo obrazotvorchoho mystetstva i muzychnoi literatury URSR [in Ukrainian].

Voropaieva, T. (2016). Rol Osobystosti v Ukrainskii Istorii kriz Pryzmu Biohrafistyky [The Role of Personality in Ukrainian History through Biographical Studies]. Ukrainska Biohrafistyka [Biographistica Ukrainica], 14, 50-70 [in Ukrainian].

Zhyrov, O. (2007). Rozvytok Ukrainskoi Narodnoi Khoreohrafii u Mystetsko-Pedahohichnii Spadshchyni ta Diialnosti K. Vasylenka (50-90 roky XX st.) [Development of Ukrainian Folk Choreography in the Artistic and Pedagogical Heritage and Activity of K. Vasylenko (50-90s of the XX Century)] [PhD Dissertation, Zhytomyr Ivan Franko State University] [in Ukrainian]. 